\title{
Sciendo
}

\section{Gender in Fulani Proverbs}

\section{SERGIO BALDI* - RUDOLF LEGER**}

* Department of Asian, African and Mediterranean Studies Università degli Studi di Napoli “L’Orientale”, Napoli, Italy sbaldi@iuo.it

** Institute of African Studies

J. W. Goethe-Universität, Frankfurt am Main, Germany leger@em.uni-frankfurt.de

\begin{abstract}
Presented paper deals with Fulani people of West Africa and with the influence of their way of life on their language. One part of the Fulani people lives nomadic pastoral live, meanwhile another part is sedentary, living in the towns. The authors of the paper pay their attention to the the gender of Fulani proverbs which reflects the way of life of Fulani people.
\end{abstract}

KEY WORDS: Fulani, proverbs, linguistics, pastoralism, sedentarism, West Africa

The Fulani (after their self-denomination Fulbe, sig. Pullo) also known as Fula, Afuli, Poular or Peul, are the largest migrant peoples in West Africa (JUNGRAITHMAYR - ABUMANGA 1989:xvii). Their area of extension reaches from Senegal, Guinea and Sierra Leone up to the Lake Chad and even further to the Republic of Sudan. The vast area they cover is not a unique conglomeration, but a region that spans many national borders, and contains many other peoples with different languages. The number of their speakers is estimated to be around ten to fifteen million. Fulfulde, which is the name of the language (JUNGRAITHMAYR - MÖHLIG 1983:87), can be divided into three major dialects (cf. GOTTSCHLIGG 1992:49f.; KLINGENHEBEN 1963:vii) which are; Western Fulfulde 
(Poular, spoken mainly in Gambia, Mali and Burkina Faso), Central and Eastern Fulfulde (both of which are mainly spoken in Niger, Nigeria, Cameroon as well as Chad and Sudan).

According to their basic economic activities and physical traits, the Fulani can be divided into two main groups. These are on the one hand the Nomadic pastoral Fulani (Fulanin daji), and on the other hand the sedentary town Fulani (Fulanin gida). The former (also named Fulbe na'i, i.e. cattle Fulani) differ in appearance and in habits from the other Sudanese peoples in whose territories they migrated to. The dialectal differences between the groups within are not as great as among the sedentary Fulani. The sedentary Fulani on the other hand have played an important role in the history of West Africa. As learned men, government officials and even poets, they had a great influence on empires like Mali and Songhay. This centuries-old tradition found its peak in the nineteenth century, when they established the Sokoto Caliphate in Northern Nigeria. The recent importance of their influence has been described as follows (ARMSTRONG 1978:19): "In the development of Africa, the modernization of the Fulani cattle industry can play a great role; and the political talents of the Fulbe of the cities will continue to be important for the national unification of countries like Nigeria and Cameroun."

The origins of the Fulani are shrouded in mystery. Fantastic theories have been established linking the original homeland of the Fulani to ancient Egypt, India, the Caucasus, Malaysia or even Polynesia. According to the above theories, they are therefore genealogically associated with the Dravidians, Gypsies, ancient Hebrews, Romans, Arabs and Berbers (cf. KRAUSE 1884:10; TAYLOR 1953:iv f.; KIRK-GREENE 1958:22). The most plausible theory is that their place of origin might have been the green Sahara from where they moved down southwards to the Senegambia region due to the progressive desertification of the Sahara.

Their language is classified under the Atlantic family of the Niger-Congo phylum and it is one of the most highly developed class languages in Africa. Many authors have commented on the flexibility, refinement and comparative richness of Fulfulde which might be due to its highly developed class nature (cf. STENNING 1965:364; LEGER in print).

Despite their involvement in so many cultures of the Sudan zone, the Fulbe have preserved a special way of life (laawol pulaaku), i.e. the code of conduct of a real Fulani. Pulaaku is a Fulani exclusive-marker that describes various components of important values and virtues. It comprises components of which the most important are: seemteende, i.e. 'modesty and reserve', munyal, 'patience and fortitude', endam 'compassion and kindness, ngorgu 'manliness and bravery', hakkiilo 'care and forethought' and above all neddaaku 'dignity or self-respect’ (cf. RIESMAN 1977:127f.; STENNING 1965:369). These important values and 
virtues, always determine their attitude towards various family members in particular and the clan in general. This can be best demonstrated by the many proverbs dealing with this fact. Proverbs basically condense a much more elaborated way of how men should behave to their female partners. This may be illustrated further through the following proverbs which we subsume under the above mentioned corner stone of Puulaaku.

\section{Seemteende 'modesty and reserve'}

Modesty and reserve are one of the main principles a "real Pullo" must observe during his entire life.

Modesty and reserve does not only concern his individual being, but also effects his behavior towards his family, and here in particular towards his children and his wife(s). The following proverbs may give a clear proof of seemteende:

Too korema soodi mbeewa cooda fowru." If your wife buys a goat, buy a hyena."

This proverb is an excellent statement of how cooperation between men and women should function. At a first glance there seems to be a contradiction. When a married woman buys a goat - although someone not specified, but here evidently referring to the husband - the man should buy a hyena. A hyena basically stands for something which is not of value, therefore not worth possessing, but nevertheless the noun expresses a kind of "reality". The real sense of this proverb is "Everyone is for himself". But the interpretation of the proverb says that everybody should act or behave independently although a husband and his wife should support each other at any time and in any circumstances.

Also in the same way where reserve and modesty is expressed similarly, we find the following proverb with more or less the same meaning described above. It runs as follows:

Too korema soodi geroogal cooda muиjuиru." If your wife buys a hen, buy a cat."

Here goat is substituted by a hen and the hyena by a cat.

Debbo mi tuubi rellataa a gorko." A woman, who says I am sorry, will not lack a man.” This proverb, in a straight forward manner, indicates the excuse of a woman obviously addressed to a man. The meaning is that a lady used to excusing herself with men will have 
no problem in finding a husband. Figuratively it could mean modesty and good behaviour will open all doors. "Courtesy costs nothing."

Another proverb describing modesty is:

'E kuugal meere ndikka kuugal lawriiraawo." It is better to work for a co-wife than sit idle."

The co-wife is a rival, therefore an adversary. This proverb says, instead of sitting idle after the house chores, it is better to put aside the differences and individual pride, and help the co-wife (rival). This means one should not have problems in helping an adversary even if that will take away your free time.

\section{Munyal, 'patience and fortitude'}

Patience and fortitude is not only one of the highest virtues among the Fulani, but also in the whole of Africa. The following proverbs may illustrate the above cultural trait.

Nde dursol bursete yaa daado beera nder leeso waalata." When things were good for the first wife the young girl slept under the bed."

The interpretation of this proverb is that as long as a young girl is not married, she has to be patient and be obedient to her mother. This is expressed by the metaphorical expression "to sleep under the bed". As soon as she grows up and gets married, she can then sleep on the bed. This finally says that as she is in the process of growing up she has to be patient and heed to the advice of her parents. Another proverb depicting patience and fortitude is:

Allah wadi huunde nden inji bolwoowo teegal mum. "God made this thing said a lady who discusses her marriage."

The deeper sense of this proverb is that God has determined everything including whom the lady will marry in future. So the woman has to be patient since everything is decided by Allah. And the last proverb under this heading runs as follows:

To banngal waddaayimo ay seeruki wadday mo. "If marriage did not bring her, then divorce will bring her."

The literary translation says: "If she hasn't come for good, she will come for bad." The interpretation, however is, be $\mathrm{p}$ atient in life, what at first glance seems negative, i.e. marriage, may turn out, to be better after a divorce. 


\section{Endam 'compassion and kindness'}

Compassion and kindness is reflected in the following proverbs:

Walaa ko ngidammi ba gidando gido." There is nothing I like to see (more than) one who loves his lover." The translation gives an idea of persistent love between a man and a woman. The interpretation is that it is always nice to see two lovers.

Another proverb of this type is:

Keenya naa hannde pulodebbo yi'i ceede ngeynaari." Yesterday cannot be the same as today: an old woman saw money given to a lady for marriage."

The deep sense of the above cited proverb is that when an old lady gives money to a young lady for marriage, it reminds her of her own youth and beauty when she got married, even if it had been a long time ago. Nevertheless she does not feel jealous, but rather contributes financially to the marriage of the young lady.

And the last one for endam:

Koo moye wi bangay annda jangarle duuniyaaru." Whoever says she/he wants to marry, does not know the ups and downs of marriage."

This proverb shows how the excitement of a marriage is, and at same time an exhortation to solve the ups and downs during their life together.

\section{Ngorgu 'manliness and bravery'}

Manliness and bravery also includes how a man should behave towards his family and in particular to his wife. These facts are reflected in the following proverbs:

Giddo sonndu hannyum tokkoto e wuuba. "One who likes birds is the one who will continue throwing stones."

This proverb says that the love for your family means you will continue exerting a positive effect on it. On the other hand "continue throwing stones." means that the love for your family should not prevent you from using unpleasant methods to putting things right.

Hooweeki jeyi manti." She who is in her first husband's house boasts." 
This proverb gives another idea of manliness, although not easy to be understood at a first glance. It says that in case the husband marries another woman, he should treat the second wife as good as the first. It should be added here that the first wife naturally has certain privileges which the next wives do not have. (It could also be interpreted as "a woman in her first husband's house" has the right to be proud because she has never divorced - meaning she has never been rejected by a man).

\section{Hakkiilo 'care and forethought'}

Another virtue among the Fulani is hakkiilo, which means care and forethought. A real Fulani always has to be wise and careful in his actions and behavior towards society as well as to his clan and family. This virtue is expressed in the following proverbs.

Mi heptiiraanay dum dum fii bii lawliraawo. "I could not understand: a co-wife's son was beaten."

This proverb reflects the expectation of the husband for peace within his family. No one in the family, be it the son of a co-wife can be punished without a strong reason. There should first be a discussion within the family on how to treat a member. And only as a last measure i.e. the ultima ratio, might there be a punishment.

In nearly the same way runs the following proverb:

Mi heptaayi dum hoosi binngel lawliraawo. “ I could not understand, a co-wife's child is stolen."

Here, instead of beaten, (see above) the co-wife's son is stolen.

\section{Nedofaaku 'dignity or self-respect'}

The main virtue above all is neddaaku which means 'dignity or self-respect'. For a real Fulani everything centers around neddaaku. i.e. expressed in the following proverbs:

Lawliiru boyloowa rewbe tonga ummake sey dum tuutiinga. " Jealousy is the nausea of women when it starts it has to be vomited." 
This proverb states how it is very difficult to hide jealousy. It is of course not always easy to suppress or even hide jealousy in a polygamous society. But nonetheless, it is considered shameful for a debbo Pullo (i.e. Fulani woman). It is an important part of Fulani sense of dignity not to display one's feelings in public.

To walaa booraajo walaa moowaajo (Hausa). "If there is no unloved wife there won't be a loved wife."

This proverb also refers to dignity or self-respect. A woman, who is no more loved by her husband, is not supposed to show her feelings to the other members of the family. Jealousy should be controlled, and not revealed to other family members.

This proverb, in a rather negative way, depicts how difficult cohabitation can be within the family.

Debbo to'o yid i gorko o huda baaba mum to'o wanyii dum'o wula wuro, mum. "If a woman loves a man, she abuses his father, if she hates him, she sets the town ablaze."

The real meaning of the proverb is that once a lady is married, she has to be loyal to her husband much more than to her original family. It furthermore depicts a situation of real unhappiness if disappointed by her husband. Going so far as disobeying a serious cultural norm like "setting the town ablaze".

\section{Conclusion}

Our paper cannot fully express the concept of Pulaaku no matter how much one tries to condense it, since apart from the above mentioned cornerstones there are much more important qualities appropriate to a Fulani. Just to mention in addition some few more is the concept of beauty and the way how a pastoral Fulani has to take care about his livestock. A Fulani woman e.g. has to have according to Pulaaku dark hair like the night, dense and long enough to cover the lady's back down to the waist. Her face is shining like a mirror, so that you can see your own face reflecting in it. The nose is thin and tiny, the mouth is small and to be compared to the local ink pot. The neck is that of a gazelle, the waist is in harmony with the proportions of all other members of the body and usually described as narrow as that of a mason wasp and defeat a soft and small. 
What concerns the livestock then a real Fulani has to take care of it day and night, watch about the movements of the cattle and whether there are some hitherto unknown diseases among the animals. However, we strongly believe this paper has shown to a certain extent some important proverbs restricted to how women and men should interact within the framework of the traditional Fulani virtues. It should also stimulate those interested in Fulfulde studies and in particular about the relationship between men and women to read more on this topic. We would like to emphasise the collaboration of Malam Bappayo Bappah Yerima Djibril who has collected most of the proverbs of the Gombe dialect (North Eastern Nigeria) during the special research of the Frankfurt University in the years 1989 to 2003. All the material consists of about 1800 proverbs and wise sayings which were also translated and interpreted with his valuable help. Similarities with other proverbs already published are by chance and not taken from these data.

\section{Bibliography}

ARMSTRONG, Robert G. (1978): The development of Fulani studies: A linguist's view. In Struktur und Wandel afrikanischer Sprachen (Marburger Studies zur Afrika- und Asienkunde: Bd. 17), hrsg von H. Jungraithmayr. Berlin. Dietrich Reimer Verlag, pp.190.

BALDI, Sergio (2015): Proverbs as an educational factor in Hausa society. In Gianclaudio Batic, Sergio Baldi (eds.): Actes of Symposium on West African Languages

(SyWAL2014, Naples, 27-28 March 2014). Naples: University of Naples L'Orientale: Department of Asian, African and Mediterranean Studies.

BALDI, Sergio - LEGER Rudolf in print: Gender in Hausa and Igbo proverbs, paper presented to 15th Afro-Asiatic Meeting (Rome, 17 to 19 September 2014), at Sapienza University.

GOTTSCHLIGG, Peter (1992): Verbale Valenz und Kasus im Ful. Wien. Dissertationen der Universität Wien.

JUNGRAITHMAYR, Herrmann - ABU-MANGA AI-Amin (1989): Einführung in die FulSprache (Sprache und Oralität in Afrika: Bd. 1). Berlin. Dietrich Reimer Verlag.

JUNGRAITHMAYR, Herrmann - MÖHLIG, Wilhelm J. G. (1983): Lexikon der Afrikanistik. Berlin: Dietrich Reimer Verlag.

KIRK-GREENE, Anthony H. M. (1958): Adamawa Past and Present. An Historical Approach to the Development of a Northern Cameroons Province. London: Oxford University Press for International African Institute. 
KLINGENHEBEN, August (1963): Die Sprache der Ful (Dialekt von Adamawa). Hamburg: Verlag J. J. Augustin.

KRAUSE, GOTTLOB A. (1884): Ein Beitrage zur Kenntnis der Fulischen Sprache in Afrika. Leipzig: F.A. Brockhaus.

LEGER, Rudolf (2014): I Want to Be My Own Cow. Fulani Names and Superstitions about Their Cows. In Hannelore Vögele, Uta Reuster-Jahn, Ursula Baumgardt, Raimund Kastenholz (eds.): From the Tana River to Lake Chad. Research in African Oratures and Literatures. In memoriam Thomas Geider. Köln: Rüdiger Köppe, pp. 185-194.

RIESMAN, Paul (1977): Freedom in Fulani Social Life. Chicago: University of Chicago Press. [Translation of Société et liberté chez les Peul djelgobe de Haute-Volta by Martha Fuller].

STENNING, Derrick J. (1965): The Pastoral Fulani of Northern Nigeria. In James L. Gibbs Jr. (ed.): Peoples of Africa. Holt, Rinehart \& Winston: New York, Chicago, San Francisco, Toronto, London, pp. 363-401.

TAYLOR, F. W. (1953): A Grammar of the Adamawa Dialect of the Fulani Language (Fulfulde). Berlin.

WHITTING, Charles E. J. (1940): Hausa and Fulani proverbs. Lagos: Government Printerp. [Reprint 1967. Farnborough. Gregg International.]. 